\title{
Soil conditions in a small catchment on the Loess Plateau in China
}

\author{
Ingmar Messing ${ }^{\mathrm{a}, *}$, Liding Chen ${ }^{\mathrm{b}}$, Rudi $\operatorname{Hessel}^{\mathrm{c}}$ \\ ${ }^{a}$ Department of Soil Sciences, Swedish University of Agricultural Sciences, Box 7014, \\ SE-750 07 Uppsala, Sweden \\ ${ }^{\mathrm{b}}$ Department of System Ecology, Research Center For Eco-Environmental Sciences, \\ The Chinese Academy of Sciences, P.O. Box 2871, Beijing 100085, China \\ ${ }^{\mathrm{c}}$ Department of Physical Geography, Utrecht University, P.O. Box 80.115, 3508 TC Utrecht, The Netherlands
}

\begin{abstract}
This article presents the results from soil surveys carried out within the framework of a soil conservation research project with several components: soil erosion modelling, land evaluation and participatory planning. The study area was a small catchment $\left(3.5 \mathrm{~km}^{2}\right)$, ranging in altitude between 1085 and $1370 \mathrm{~m}$, in the vast Loess Plateau area in northern China. It is continuously affected by soil erosion by water, to a certain extent due to the unprotected slopes resulting from cultivation of subsistence food by the land users. The information on variability of soil properties in the study catchment was required as a basis for development of land use scenarios opting for ecological and economical sustainable production for the land users in the future. Soil profiles to $1-\mathrm{m}$ depth were described, using FAO guidelines, at 17 sites along two transects covering the different facets of the morphology: hilltop, hillslope, valley bottom. Samples were collected from each horizon in the soil profiles for laboratory determination of physical and chemical properties. It was found that the nutrient status of the soils was poor, with ranges in contents of: sand $=6.5-30.0 \%$, silt $=53.5-$ $74.5 \%$, clay $=11.1-29.0 \%$, organic matter $=0.11-1.32 \%$, available $\mathrm{P}=0.1-11 \mathrm{ppm}$, available $\mathrm{N}=5-56 \mathrm{ppm}$. The extremely high $\mathrm{pH}$ values, ranging between 8.7 and 9.3, effectively restricted the availability of nutrients. The soils have a high available water storage capacity so that, during years with a good supply of rain water, fair yields of crops can be achieved if the soil is fertilised. However, during dry years, when the soil dries out, the soils are vulnerable to drought and the crops fail. A divide at approximately 1200 to $1225 \mathrm{~m}$ above sea level was found between stratified and unstratified loessial soils. Above this altitude, the soils were yellowish, homogeneous silt loams with no or few restrictions for tillage, root penetration or water percolation. Below this altitude, layers that were more reddish (due to soil processes during climatically wetter periods), slightly cemented or higher in clay content, although still having a silt loam texture, were found in the soil profiles. These
\end{abstract}

* Corresponding author. Tel.: +46-18671173; fax: +46-18672795.

E-mail address: Ingmar.Messing@mv.slu.se (I. Messing). 
layers could cause problems at tillage, and could give rise to some restrictions to root penetration and water percolation, thereby increasing the erosion risk. A partitioning into characteristic soil types is proposed, to be used in the other parts of the project: erosion modelling, land evaluation and participatory planning.

(C) 2003 Elsevier Science B.V. All rights reserved.

Keywords: Loess Plateau; China; Land use; Soil erosion; Soil nutrients; Soil properties

\section{Introduction}

Loessial deposits are widespread in China between latitudes $33^{\circ} \mathrm{N}$ and $47^{\circ} \mathrm{N}$, and longitudes $75^{\circ} \mathrm{E}$ and $125^{\circ} \mathrm{E}$, constituting the so-called "Loess Plateau". They represent an accumulation of wind-borne dust and silt derived from disintegration of superficial rocks in desert and arid areas to the north and west (Liu et al., 1985). The deposits range up to several hundred metres in thickness and cover an area of $440,000 \mathrm{~km}^{2}$.

Since the early Pleistocene era, there have been numerous periods of desertification, loess deposition and palaeosol formation; aeolian sand and loess accumulate during cold and dry climates, and palaeosols form on these deposits during relatively warm periods with higher humidity. A 140-m-thick loess profile transect at Luochuan in central Shaanxi province was described by Liu et al. (1985) showing the stratification summarised in the following of this paragraph, and is similar to the transects found in the study catchment. Four major units of loessial deposits with interlayered palaeosols have been recognised (Liu et al., 1985). The lowest, Wucheng Loess, is an early Pleistocene, reddish to lightbrown, well-cemented and relatively fine-grained loess. It reaches up to 100-m thick and rests conformably on reddish clays of Late Pliocene age. This is a good representation of the Pliocene-Pleistocene boundary, during which many biological and climatic changes occurred. The overlying Middle Pleistocene Lishi Loess is greyish brown with poorly cemented upper portions. The thickness generally ranges between 40 and $70 \mathrm{~m}$, rarely as great as $200 \mathrm{~m}$. The late Pleistocene Malan Loess is greyish yellow, loosely cemented, coarse grained and contains substantial amount of unstable minerals. The total thickness is generally $10-30 \mathrm{~m}$. At the top of the section, there is a thin, 2-3 $\mathrm{m}$ loess of Holocene age. This is greyish yellow in colour and very loose. Generally, this soil has become incorporated in the Malan loess as a result of bioturbation and pedogenesis.

The hilly area of the Loess Plateau of China has a very high rate of erosion, averaging $150 \mathrm{Mg} \mathrm{ha}^{-1}$ year $^{-1}$ (Chen and Luk, 1989). This is equivalent to a surface lowering of $1.2 \mathrm{~cm}$ year $^{-1}$. One reason for the soil erosion and associated nutrient loss is the intensive cultivation of the sloping land (Fu, 1989). The study reported here was part of a soil conservation research project in a small catchment on the Loess Plateau with the principal components of soil erosion modelling, land evaluation and participatory land use planning. The objective of the present study was to define the depth distribution of soil horizons and their properties in the uppermost metre of representative soil profiles. The information was critical for extrapolating the results to the entire catchment, to be used in the soil erosion modelling and land evaluation parts of the project. The use of the soils from an agronomic 
point of view was important and the properties and names of the soils as described by the farmers in the catchment were compared with our observations and analyses of the soils. Very few results from studies of properties of soils from the Loess Plateau in China have been presented in English.

\section{Materials and methods}

\subsection{Study area}

The study area, Danangou catchment $\left(36^{\circ} 56 \mathrm{~N}, 109^{\circ} 17 \mathrm{E}\right)$, is located in the middle part of the Loess Plateau in the northern part of Shaanxi Province. It is approximately $5 \mathrm{~km}$ to the north of Ansai, on the western side of the Yanhe river. The catchment covers an area of 3.5 $\mathrm{km}^{2}$ and encompasses two villages, Leipingta and Danangou, with approximately 25 families in each, most of them dependent on subsistence agriculture. There are important topographic variations in the catchment, with several subcatchments (Fig. 1). The long and narrow hilltop ranges have sharp transitions into steep gully sides and narrow valley bottoms. Several faces of landslides with slope gradients smaller than the adjacent gully side slope gradients occur. The outlet of the catchment is at $1085 \mathrm{~m}$ above sea level, and the highest hilltop reaches $1370 \mathrm{~m}$. The region has a semiarid continental climate with an average annual rainfall of $513 \mathrm{~mm}$ (Ansai climate station 1971-1998). The land use in the

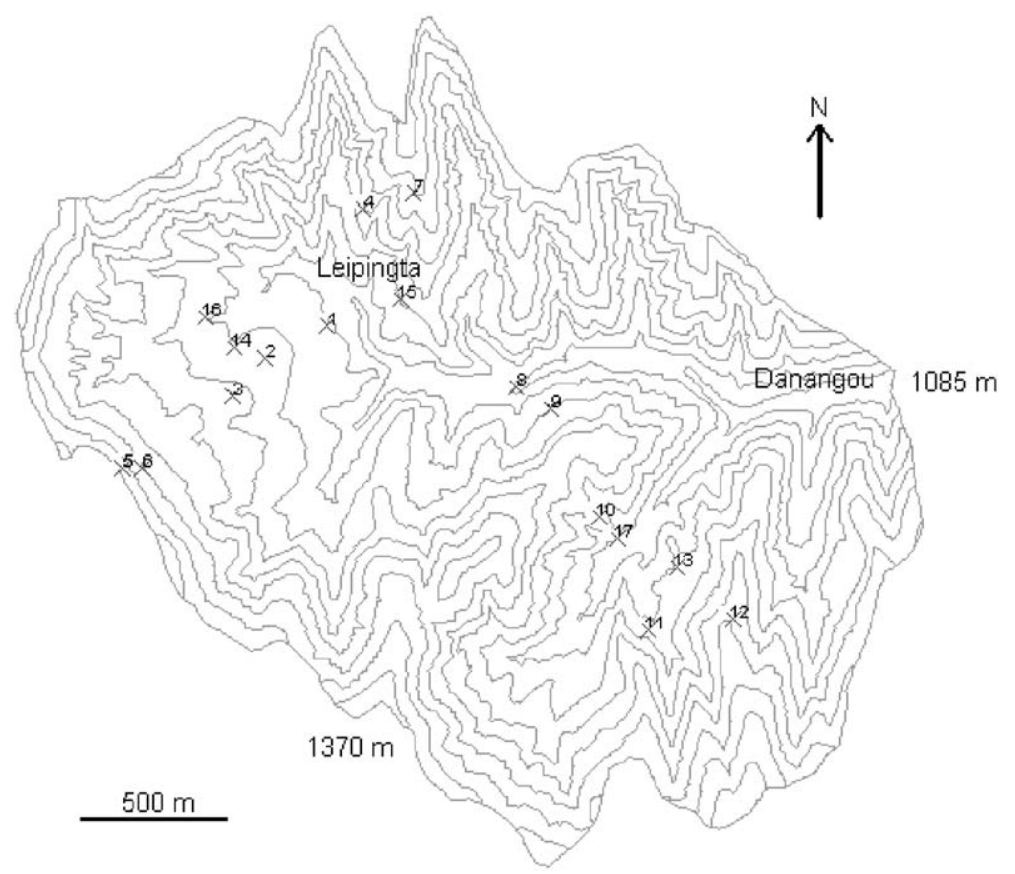

Fig. 1. Topography and position of the sites of soil profiles in Danangou catchment. 
catchment as a whole during 1998 constituted $44.2 \%$ cropland (of which $7.2 \%$ fallow), $2.4 \%$ orchard, $11.7 \%$ woodland, $1.2 \%$ shrubland, $40.5 \%$ wild grassland.

\subsection{Local soil names and soil properties}

The land users in the catchment were asked to characterise their soil types in a participatory rural appraisal (PRA) survey carried out at the same time as the present soil survey. Four types were distinguished: (i) Huangtu (huang=yellow; tu= soil), soft yellowish loess of a silt character, usually found on top of the hills and on upper and middle parts of the hillslopes. This was considered to be the best soil because of its softness and lightness, good conditions for root and water penetration, good water holding capacity and ease of tillage. (ii) Huangjiaotu (jiao = hard/clayey), hard yellowish soil of a clayey silt character, usually found in the lower parts of the hillslopes, which was considered to be good but could become hard, especially when subjected to drying after periods of heavy precipitation, and problematic for root and water penetration and for tillage. (iii) Hongjiaotu (hong=red), reddish clayey character with moderate blocky structure, usually found in the lower parts of the slopes and valley bottoms, difficult to till and if exposed on steep slopes poor in water. (iv) Jifentu, a reddish clayey character with platy moderate to strong structure (better structured than Hongjiaotu), usually found in the lower parts of the slopes and valley bottoms, having better conditions for root and water penetration than Hongjiaotu. Often, Huangjiaotu had been incorporated by tillage in the overlying Huangtu and hence did not cause any constraints in the topsoil. However, if the Huangtu was lost by erosion and the underlying hard Huangjiaotu came up to the surface, which sometimes happened, tillage problems could be a result and a new topsoil had to be worked up.

A preliminary soil map was compiled prior to the present investigation. It was based on observations of geomorphology, land use and topsoil colour. The mapping units defined followed a classification of soils for the Loess Plateau based on texture, land use and erosion character (Gong, 1998; Ansai County, 1985). The catchment consisted of: (i) loessial soils, covering $95 \%$ of the catchment area, and occurring on hilltops and hillslopes; (ii) alluvial soils, 1\%, occurring only in the valley bottoms and; (iii) skeletal soils, $4 \%$, in the lower parts of the hillslopes and in valley bottoms.

The loessial soil group, which is the predominant type in the area, evolved directly from the parent wind-deposited yellow material. In general, the texture is silt loam, the content of clay sized particles being $8-30 \%$, the dry bulk density of the cultivated layer $1.10-1.30$

$\mathrm{g} \mathrm{cm}^{-3}$, CEC 5-7 meq per $100 \mathrm{~g}$, the content of $\mathrm{CaCO}_{3} 10-16 \%$, and the organic material $0.5-1.5 \%$. On the Soil Map of the World (FAO-UNESCO, 1974), the soils in this part of the Loess Plateau, orientated in a southwest/northeast belt, are classified as Calcic Cambisols. In the southeast, a belt of Chromic and Eutric Cambisols is found and in northwest there is a belt of Luvic Kastanozems-Luvic Xerosols-Calcic Yermosolsdunes/shifting sand.

\subsection{Methods and execution}

The soils at 17 sites were selected for detailed characterisation based on the following: (i) soil type from the preliminary soil map, (ii) land use, (iii) two transects (called 
Danangou and Leipingta) used also in the PRA survey, covering the range hilltophillslope-valley bottom, and (iv) the location of sampling of soil cylinders for soil physical measurement (used for the soil modelling part of the project). The sites along the two transects, numbered in chronological order of sampling, are shown in Fig. 1.

Descriptions of soil profiles to 1-m depth at the 17 sites according to FAO guidelines (FAO, 1990) were made. Each characteristic horizon in these profiles was sampled to determine soil particle size class and soil chemical status. After removal of gravel by sieving, the sand, silt and clay contents of the soil were determined in $1000-\mathrm{ml}$ soil solution with $30 \mathrm{~g}$ of soil (dispersed by $\left.\left(\mathrm{NaPO}_{3}\right)_{6}\right)$ and the settling rates measured by the hydrometer method. Other measurements included: organic matter (OM) (Bremner and Jenkinson $\mathrm{K}_{2} \mathrm{Cr}_{2} \mathrm{O}_{7}$ method) (Nelson and Sommers, 1982), available nitrogen (N) ( $\mathrm{NaOH}$ extraction and distilling), total N (Micro-Kjeldahl method) (Bremner and Mulvaney, 1982), available phosphorous (P) (Olsen method) (Olsen and Sommers, 1982), total P $\left(\mathrm{HClO}_{4}-\mathrm{H}_{2} \mathrm{SO}_{4}\right.$ extraction), and soil reaction $(\mathrm{pH})($ Soil/water $=1: 5$, mixing for $30 \mathrm{~min}$ by shaking, electrolytic method). The properties here analysed, chosen jointly with local researchers, were considered important from the point of view of soil erosion and land evaluation in the area, and complemented other measurements carried out within the project.

A lithology map was compiled based on a field investigation of the spatial distribution of material observed in the land surface. The map was to be used in soil erosion modeling of different land use scenarios developed in the project.

\section{Results and discussion}

\subsection{Variation within the transects}

The relative position of the sites on the two transects and their variations in horizon depths, texture and colour are presented in Figs. 1-3. The upper parts of the hillslopes and hilltops consisted of homogeneous yellowish, 10YR in standard soil colour charts (Oyama and Takehara, 1995), loess with very little horizontal stratification (profiles No. 3, 5, 6, 7 and 12). These were derived from Malan loess deposits (Liu et al., 1985), and were called Huangtu by the local farmers.

The lower parts of the slopes, on the other hand, consisted of stratified soils, both regarding texture and colours. Thus, in extreme cases, a soil profile (e.g. profile No. 1) could consist of alternate layers of loose yellowish silt loam almost in single grain structure (Huangtu), slightly reversibly cemented weakly structured and clayey yellowish/ reddish silt loam (Huangjiaotu), clayey reddish/yellowish silt loam with strong platy structure (Jifentu) and clayey reddish silt loam with moderate angular/subangular structure (Hongjiaotu). These soils, derived from the Lishi and Wucheng loess deposits, had been exposed to palaeosolic development during more humid periods (Liu et al., 1985) giving rise to the reddish colours found, 7.5YR and 5YR in standard soil colour charts (Oyama and Takehara, 1995). These older deposits have undergone alteration (e.g. cementation, weathering) and the main body has relatively compact and stable structure and is noncollapsible when wetted, except in the upper layers, which are sometimes slightly 
collapsible (Lin and Liang, 1982). Profiles No. 1, 2, 9, 11, 13, 14, 15 and 16 were characterised by having layers with both higher clay content or structure development and a more reddish hue than the other profiles. Profile No. 4 had a higher clay content but not a reddish, but a dull, yellowish colour, and profiles No. 10 and 17 only had colour development to more reddish hue, but no increased clay content or structural development. Profile No. 16 had a continuous layer of calcareous concretions at the bottom of the second horizon at approximately $0.5 \mathrm{~m}$ depth. This was found also below $1 \mathrm{~m}$ depth in profile No. 1 , and seemed to occur at some depth in most soils in the lower part of the catchment. The horizons with layers of calcareous concretions belong to the Lishi loess deposits (Lin and Liang, 1982).

Profile No. 8 differed from the others in that it was not formed primarily in the windborne deposits, but from water-deposited materials sedimented behind a former check dam in the valley bottom. However, the fine particles have been relocated by erosional processes on the hillslope soils, so the soil material originates from the same material as in the other profiles. The fine earth fractions were mixed with gravel, stones and boulders in some of the horizons.

Water erosion and landslides are recurrent processes in the area and, by that, a certain redistribution of soils has taken place, causing complex soil relationships. However, a divide between the unstratified loessial soils (above) and the stratified ones (below) was approximately estimated to occur at $1200 \mathrm{~m}$ altitude (above sea level) at the Danagou transect (Fig. 2) and at $1225 \mathrm{~m}$ at the Leipingta transect (Fig. 3).

From the field survey, it was considered that the resistance for root penetration and water percolation was less on the more loose unstratified yellowish soils. This was also confirmed by the farmers in the area. In the stratified soils, however, some resistance could affect plant roots. For example, it was observed in profile No. 1 that the maize roots had some problems penetrating the $\mathrm{C} 1$ layer (Huangjiaotu), and were only growing along planar cracks. The farmers admitted that some tillage problems could occur during dry periods of the season, if the clayey layers (Huangjiaotu or Hongjiaotu) were close to the surface. Some farmers considered that these layers could reduce the root and water penetrability in the soil. According to our observations, restricted root depth could also occur in alluvial soils of main valley bottoms due to gravel layers (e.g. profile No. 8), in steep parts where the loessial soils are eroded and the bedrock occurs close to the soil surface and in the skeletal soils of main valley bottoms (close to bedrock).

\subsection{Soil physical and chemical properties}

The $\mathrm{pH}$ was high $(>8.7)$ in all horizons and the soil texture for all soils was silt loam, but with varying proportions of sand/silt/clay (Tables 1-3). Gravel and larger particle size fractions only occurred at three of the sites: $4.3-58.1 \%$ of total soil mass in a stratified alluvial deposit (profile No. 8; formed behind a former dam), 90\% at $82 \mathrm{~cm}$ depth in a red loessial soil (profile No. 9; transition layer to bedrock) and $2.4-9.9 \%$ in material from a land slide on a steep slope (profile No. 11) (see Figs. 1-3). In comparison with international tables of crop nutrient demand (e.g. Landon, 1991), the values of $\mathrm{pH}$ were very large and those of OM, P and $\mathrm{N}$ were very small (Tables 1-3). Larger average, minimum and maximum values of $\mathrm{OM}, \mathrm{P}$ and $\mathrm{N}$ were found in the uppermost horizons 
$\underline{1300 \mathrm{~m}}$

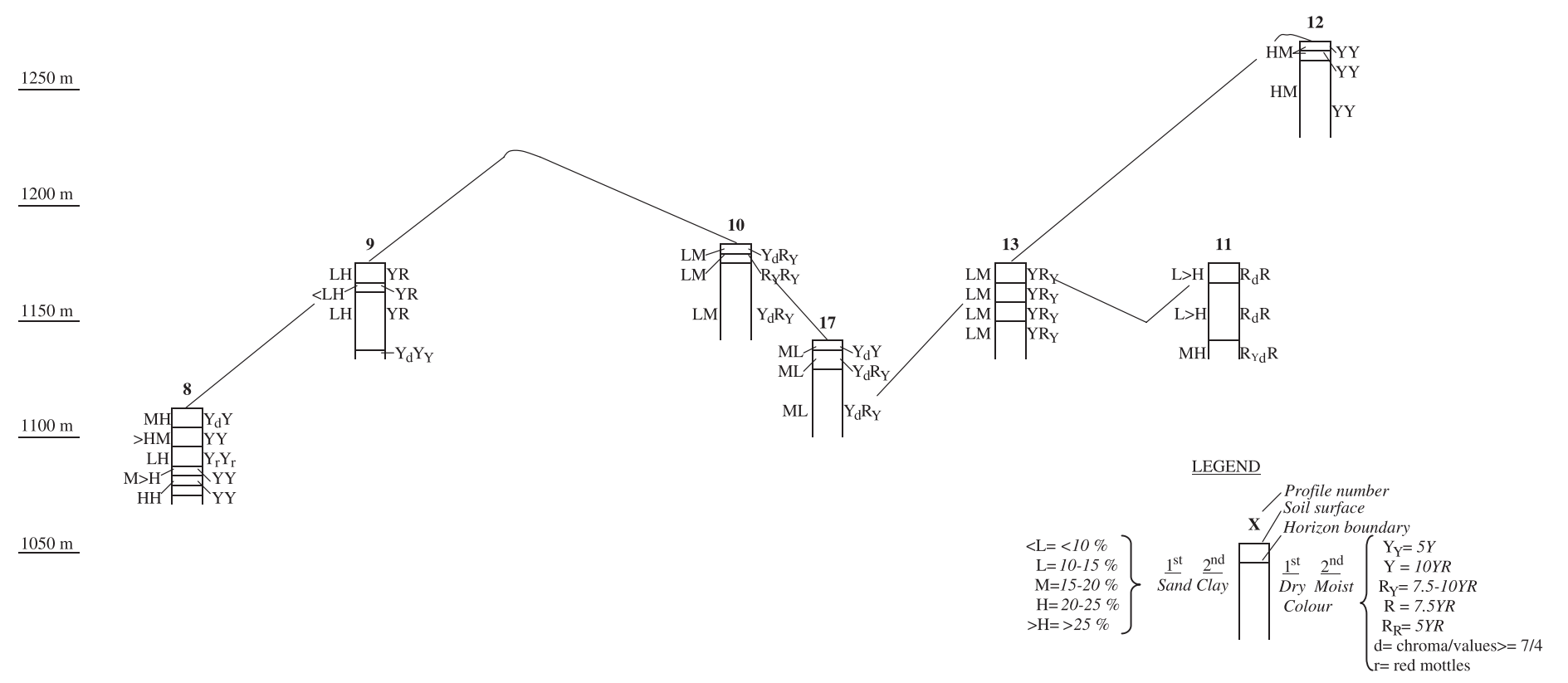

Fig. 2. Schematic cross section of the Danangou transect and its sites of soil profiles (the lines joining the sites do not represent the exact shape of the land surface). Texture (sand and clay contents of fine earth fraction) is given to the left and colour to the right of each profile. For gravel and larger particle size fractions in profiles 8,9 and 11 , see text. Length over the total cross section (horizontal) equals $920 \mathrm{~m}$. 
Altitude

$\underline{1350 \mathrm{~m}}$

LEIPINGTA
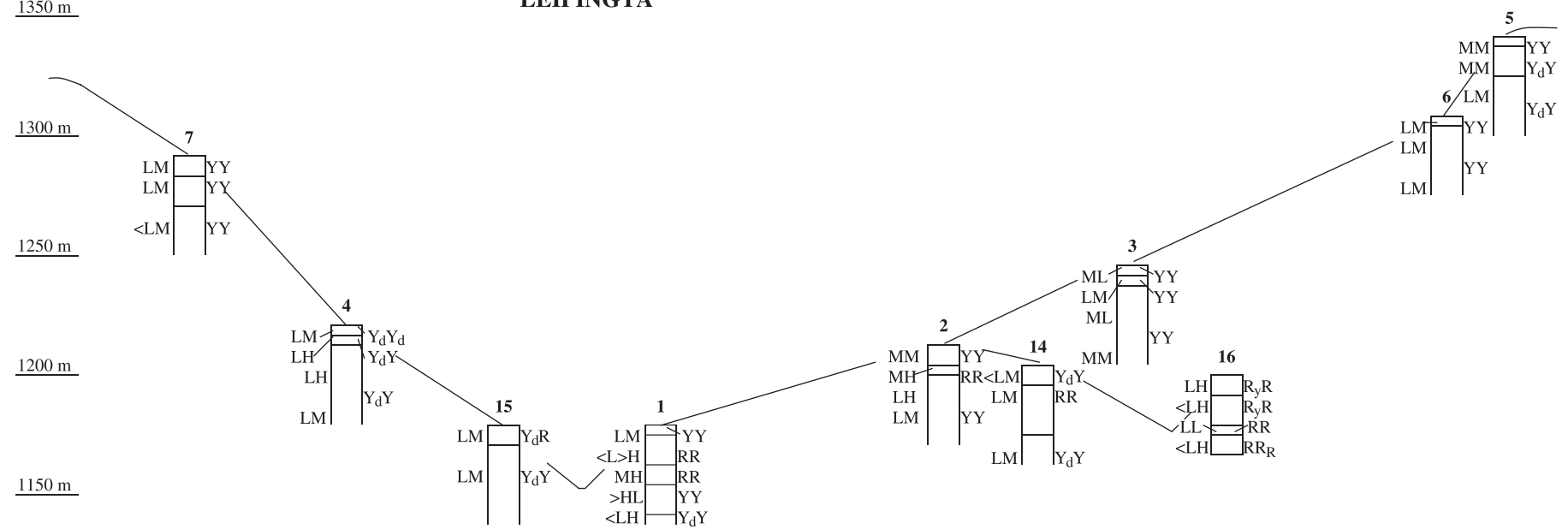

$\underline{1100 \mathrm{~m}}$

LEGEND

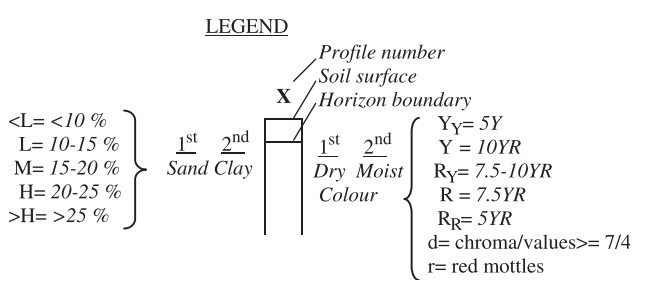

$1050 \mathrm{~m}$

Fig. 3. Schematic cross section of the Leipingta transect and its sites of soil profiles (the lines joining the sites do not represent the exact shape of the land surface). Texture (sand and clay contents of fine earth fraction) is given to the left and colour to the right of each profile. Length over the total cross section (horizontal) equals $1110 \mathrm{~m}$. 
Table 1

Average, minimum and maximum values of soil properties in top horizon (TH) $(n=5)$ and underlying subhorizons $(\mathrm{SH})(n=10)$ in loessial soils (unstratified) above $1200-1225 \mathrm{~m}$ altitude

\begin{tabular}{|c|c|c|c|c|c|c|}
\hline & \multicolumn{2}{|c|}{ Average } & \multicolumn{2}{|c|}{ Minimum } & \multicolumn{2}{|c|}{ Maximum } \\
\hline & $\mathrm{TH}$ & $\mathrm{SH}$ & $\mathrm{TH}$ & $\mathrm{SH}$ & $\mathrm{TH}$ & $\mathrm{SH}$ \\
\hline Sand (\%) & 16.5 & 14.4 & 13.7 & 8.5 & 20.0 & 20.7 \\
\hline Silt (\%) & 65.6 & 68.9 & 60.9 & 64.3 & 68.3 & 72.8 \\
\hline Clay $(\%)$ & 17.8 & 16.8 & 14.6 & 14.9 & 19.2 & 18.7 \\
\hline $\mathrm{pH}$ & 8.84 & 8.92 & 8.82 & 8.81 & 8.90 & 8.98 \\
\hline OM (\%) & 0.52 & 0.27 & 0.37 & 0.18 & 0.86 & 0.43 \\
\hline Available P (mg kg-1) & 1.4 & 0.7 & 0.9 & 0.1 & 2.0 & 1.6 \\
\hline Total P (\%) & 0.056 & 0.056 & 0.054 & 0.052 & 0.060 & 0.059 \\
\hline Available $\mathrm{N}\left(\mathrm{mg} \mathrm{kg}^{-1}\right)$ & 22.6 & 13.5 & 14.9 & 7.4 & 35.2 & 25.4 \\
\hline Total N (\%) & 0.034 & 0.020 & 0.026 & 0.013 & 0.052 & 0.031 \\
\hline
\end{tabular}

than in the underlying ones. Average values (and ranges) of OM, available $\mathrm{P}$ and available $\mathrm{N}$ were smaller in the unstratified soils (Table 1) than in the stratified soils (Table 2). This could partly be explained by the fact that average clay content was also smaller in the unstratified soils. Furthermore, the stratified soils were more likely to be fertilised since they were located closer to the homesteads. The site with alluvial soil (profile No. 8) tended to have the same average and range of the nutrient values (Table 3) as the unstratified soils. This may suggest that most fine earth material found in the alluvial soils derives from eroded Huangtu soil layers, and that the latter are more erodible than the Huangjiaotu and Hongjiaotu layers.

It was noticed that available $\mathrm{P}$ was higher in fields close to the farms on loessial soils where $\mathrm{P}$ fertilisation (in the form of fertiliser and/or manure) had been performed, especially so on the slopes just southwest of Leipingta village (profiles No. 1 and 2) (Figs. 1 and 3). Only six horizons (all in profiles No. 1 and 2) of 59 analysed showed values of available $\mathrm{P}$ greater than $4 \mathrm{ppm}$, below which the soils would be considered to have a deficiency (Landon, 1991). Total P did not vary much between the sites, so P availability seemed to be exclusively related to any external inputs of $\mathrm{P}$. The contents of

Table 2

Average, minimum and maximum values of soil properties in top horizon (TH) $(n=11)$ and underlying subhorizons $(\mathrm{SH})(n=28)$ in loessial soils (stratified) below $1200-1225 \mathrm{~m}$ altitude

\begin{tabular}{|c|c|c|c|c|c|c|}
\hline & \multicolumn{2}{|c|}{ Average } & \multicolumn{2}{|c|}{ Minimum } & \multicolumn{2}{|c|}{ Maximum } \\
\hline & $\mathrm{TH}$ & $\mathrm{SH}$ & $\mathrm{TH}$ & $\mathrm{SH}$ & $\mathrm{TH}$ & $\mathrm{SH}$ \\
\hline Sand $(\%)$ & 13.0 & 12.4 & 9.5 & 6.5 & 19.8 & 30.0 \\
\hline Silt (\%) & 68.3 & 68.1 & 60.2 & 55.5 & 74.5 & 73.7 \\
\hline Clay $(\%)$ & 18.6 & 19.5 & 11.1 & 11.6 & 26.2 & 29.0 \\
\hline $\mathrm{pH}$ & 8.85 & 8.92 & 8.70 & 8.75 & 9.27 & 9.22 \\
\hline OM (\%) & 0.70 & 0.35 & 0.19 & 0.11 & 1.32 & 0.74 \\
\hline Available $\mathrm{P}\left(\mathrm{mg} \mathrm{kg}^{-1}\right)$ & 2.4 & 2.2 & 0.1 & 0.1 & 8.4 & 11.3 \\
\hline Total P (\%) & 0.058 & 0.054 & 0.049 & 0.014 & 0.063 & 0.061 \\
\hline Available $\mathrm{N}\left(\mathrm{mg} \mathrm{kg}^{-1}\right)$ & 29.7 & 14.2 & 8.5 & 5.1 & 56.1 & 32.1 \\
\hline Total N (\%) & 0.043 & 0.026 & 0.015 & 0.010 & 0.075 & 0.056 \\
\hline
\end{tabular}


Table 3

Average, minimum and maximum values of soil properties in top horizon (TH) ( $n=1)$ and underlying subhorizons $(\mathrm{SH})(n=4)$ in alluvial soil

\begin{tabular}{|c|c|c|c|c|c|c|}
\hline & \multicolumn{2}{|c|}{ Average } & \multicolumn{2}{|c|}{ Minimum } & \multicolumn{2}{|c|}{ Maximum } \\
\hline & $\mathrm{TH}$ & $\mathrm{SH}$ & $\mathrm{TH}$ & SH & $\mathrm{TH}$ & $\mathrm{SH}$ \\
\hline Sand $(\%)$ & 19.2 & 20.9 & 19.2 & 13.5 & 19.2 & 28.0 \\
\hline Silt (\%) & 59.7 & 56.6 & 59.7 & 53.5 & 59.7 & 61.7 \\
\hline Clay $(\%)$ & 21.1 & 22.5 & 21.1 & 18.5 & 21.1 & 25.2 \\
\hline $\mathrm{pH}$ & 8.78 & 8.94 & 8.78 & 8.78 & 8.78 & 9.09 \\
\hline OM $(\%)$ & 0.68 & 0.36 & 0.68 & 0.17 & 0.68 & 0.51 \\
\hline Available $\mathrm{P}\left(\mathrm{mg} \mathrm{kg}^{-1}\right)$ & 1.8 & 0.9 & 1.8 & 0.1 & 1.8 & 1.6 \\
\hline Total P (\%) & 0.057 & 0.055 & 0.057 & 0.055 & 0.057 & 0.056 \\
\hline Available $\mathrm{N}\left(\mathrm{mg} \mathrm{kg}^{-1}\right)$ & 27.4 & 19.7 & 27.4 & 9.5 & 27.4 & 28.8 \\
\hline Total N (\%) & 0.041 & 0.033 & 0.041 & 0.019 & 0.041 & 0.040 \\
\hline
\end{tabular}

$\mathrm{OM}$ and $\mathrm{N}$ were also somewhat dependent on land use management, larger values being found in the topsoil of woodland on loessial soils (whereas $\mathrm{P}$ values were lower) (profiles No. 4 and 14) (Figs. 1 and 3). On intensively cultivated loessial soils, on the other hand, $\mathrm{OM}$ and $\mathrm{N}$ values were lower.

Even with measures taken to improve the $\mathrm{P}$ and $\mathrm{N}$ status, the crops would still suffer from the very large $\mathrm{pH}$ values, which bring about poor availability of a number of nutrients for the crops (Landon, 1991). Measures to lower the $\mathrm{pH}$ could be taken into consideration. Of the sites in the study, $\mathrm{pH}$ was somewhat lower on the loessial soils, which were predominantly used for crop/fallow, possibly implying that cropping activities can cause $\mathrm{pH}$ to decrease. Furthermore, average $\mathrm{pH}$ values tended to be lower in the uppermost horizons than in the underlying ones (Tables $1-3$ ).

To identify possible relationships between the properties studied that can be used if results from this study are to be extrapolated to other locations in the study catchment or other catchments in the area, pairwise correlation analyses were performed on the 17 catchment profile horizons for the parameters total and available $\mathrm{P}$, total and available $\mathrm{N}$, $\mathrm{OM}, \mathrm{pH}$ and clay content. High correlations between parameters were found only between available $\mathrm{N}(\mathrm{AN})$ and total $\mathrm{N}(\mathrm{TN})\left(\mathrm{AN}=-0.3+70.5 \mathrm{TN}, r^{2}=0.81\right)$ and $\mathrm{AN}$ and $\mathrm{OM}\left(\mathrm{AN}=0.1+4.1 \mathrm{OM}, r^{2}=0.90\right)$. There was a trend for smaller $\mathrm{N}$ and $\mathrm{P}$ (available $\mathrm{P}=\mathrm{AP})$ availability with larger values of $\mathrm{pH}(\mathrm{PH})\left(\mathrm{HN}=38.3-4.1 \mathrm{PH}, r^{2}=0.20\right.$; $\mathrm{AP}=26.4-2.8 \mathrm{PH}, r^{2}=0.13$; if the profiles No. 1 and 2 , which probably have been excessively fertilised, were excluded). There was also a trend for larger $\mathrm{N}$ with increasing clay content (Clay) $\left(\mathrm{HN}=-0.1+0.1\right.$ Clay, $r^{2}=0.19$; if the uppermost horizon in the two woodland sites 4 and 14, which were in a far greater $\mathrm{N}$ range than the other sites/ horizons, was excluded).

Soil water retention characteristics at five sites (1-4 replicates), near to the 17 sites in the present study, had been determined within the framework of the project, and van Genuchten functions (van Genuchten, 1980) were fitted to the soil water pressure heads $(\psi)$ versus soil water content $(\theta)$ data pairs. These measurements were made mostly in the topsoil of the Huangtu yellow soil type. The results are assumed to be applicable to the topsoils of the sites in the present study. Generally, there was a steep gradient in the $\theta(\psi)$ 
relationship between $\psi=-1 \mathrm{~m}$ and $\psi=-10 \mathrm{~m}$. In practice, this means that the amount of rain falling during the season is critical. If $\psi$ is retained above $-10 \mathrm{~m}$ in the soil, the water status may be fairly good. The available water storage capacity here determined from the difference between $\theta$ at $\psi=-1 \mathrm{~m}$ and $\theta$ at $\psi=-10 \mathrm{~m}$, varied between $13 \%$ and $32 \%$, which are relatively large values compared to other types of soil. The critical part of the year is during the vegetation period (April to October) when most of the crops are grown. As an average, the water deficiency (rain minus potential evaporation) during this period equals $333 \mathrm{~mm}$ (Yanan climate station, 1987-1996, $40 \mathrm{~km}$ south of the study catchment).

\subsection{Soil classification}

Based on the results of the soil survey in the present article, the yellowish unstratified loessial soils above 1200-1225 m altitude were classified as Calcaric Regosols in the WRB (1998) reference system and Typic Ustorthents in the USDA (1992) system (SSS). The stratified loessial soils below 1200-1225 m belonged to Calcaric/Chromic Cambisols (WRB) and Calcic Ustochrepts/Umbric Fragiochrepts (SSS); the alluvial soils to Calcaric Fluvisols (WRB) and Typic Ustifluvents (SSS) and; the soils with rock within $25 \mathrm{~cm}$ depth or containing little fine earth (skeletal soils) to Calcaric/Lithic Leptosols (WRB) and Lithic Ustorthents (SSS).

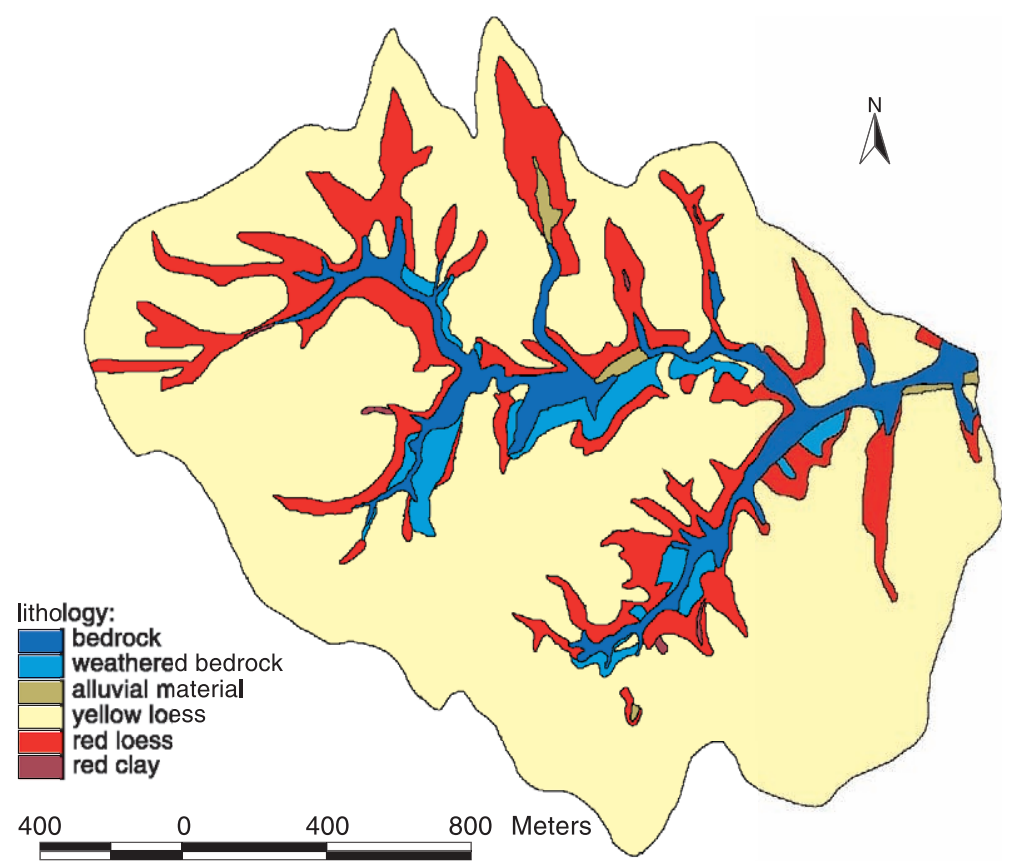

Fig. 4. Map of surface lithology to be used in scenario analyses and further planning in the area. 


\subsection{Lithology map}

In the surface lithology map, six units were identified (Fig. 4). The bedrock areas could be bare, but more often there were scattered patches of topsoil with bedrock underneath, usually within $20-40 \mathrm{~cm}$. The bedrock consisted of alternate siltstones and massive sandstone outcrops of 5- to 10-m thick. The weathered bedrock areas had a more or less continuous grass cover, some thin sandstone layers ( $\mathrm{cm}$ to $\mathrm{dm}$ scale) but with most of the surface consisting of small ( $\mathrm{mm}$ to $\mathrm{cm}$ scale) fragments that could usually be crushed by hand. When wet, however, they became slippery, indicative of silts and clays. The alluvial material consisted of deposits that have formed behind check dams constructed by farmers. The distinction between yellow loess and red loess was based on colour difference and on the occurrence of bands of secondary calcareous concretions (in the red loess). Red clay only differed from red loess in that it was more brightly red, and it covered only a very small fraction of the catchment area.

Combined with a topographical map, a further delineation can be made of the approximate divide between stratified and unstratified loessial soils at 1200-1225 m altitude.

\section{Conclusions}

When defining the sites for detailed soil profile descriptions in the present article, a preliminary soil map based on surface observations with loessial soils, alluvial soils and skeletal soils was considered, together with two transects used in a simultaneous PRA study and the location of sampling for soil water retention characteristics. It was found that the nutritional status of the soils was poor. Only on sites where intensive application of fertilisers had been performed were higher values of $\mathrm{P}$ found. In woodland soils, higher $\mathrm{N}$ values were found, although these were still low compared with the requirements for good crop production. The extremely high $\mathrm{pH}$ values effectively restricted the availability of nutrients. From a physical point of view, the soils had a high available water storage capacity, if the soil water pressure head -1 and $-10 \mathrm{~m}$ are regarded as effective limits. During years with a good supply of rain water, therefore, fair yields of crops can be achieved. However, during dry years, the soils are vulnerable to drought.

A divide at approximately 1200-1225 m altitude was found between stratified and unstratified loessial soils. Above this altitude, the soils were yellowish, homogeneous silt loams with no or few restrictions for tillage, root penetration or water percolation. Below this altitude, layers that were more reddish (due to soil processes during climatically wetter periods), slightly cemented or higher in clay content, although still having a silt loam texture, were found in the soil profiles. These layers, locally called Huangjiaotu or Hongjiaotu, could cause some problems during tillage, and could give some restrictions to root penetration and water percolation. These restrictions were acknowledged by the farmers, but not considered to be a major constraint to crop production. Since the homesteads were located in the lower parts in the catchment, the stratified soils were closer, and for that reason more fertilisers were applied to these soils. 
For use in other parts of the project (erosion modelling, land evaluation and participatory planning), it is considered that the soil distribution map can be based on the following classes:

1. Unstratified yellow loessial soils (above 1200-1225 m).

2. Stratified yellow loessial soils (below 1200-1225 m).

3. Red loessial soils.

4. Alluvial soils.

5. Weathered bedrock and bedrock (skeletal) soils.

As compared with the local soil names, the unstratified yellow loessial soils consisted exclusively of the soil type Huangtu. The stratified yellow loessial soils consisted of alternate layers of Huangtu, Huangjiaotu, Hongjiaotu and Jifentu - the topsoil being Huangtu or Huangjiaotu (giving yellow colour on the soil surface). The red loessial soils consisted of alternate layers of Huangjiaotu, Hongjiaotu and Jifentu - the topsoil being Hongjiaotu or Jifentu (giving red colour on the soil surface). As comparing the five classes above with the surface lithology map, the area of yellow loess in Fig. 4 can, when applicable, be complemented by a divide contour line (between unstratified and stratified loessial soils) at 1200- to 1225 -m altitude.

By using detailed soil profile descriptions to 1-m depth along two transects, comparing their characteristics with those defined by the farmers living in the catchment and extrapolate the results spatially with the help of a surface lithology map, a comprehensive picture of the soils in the study catchment for use within the frameworks of the project was obtained.

\section{Acknowledgements}

This article is the result of soil surveys within the scope of the EU financed project "A participatory approach for soil and water conservation planning, integrating soil erosion modeling and land evaluation, to improve the sustainability of land use on the Loess Plateau in northern China-EROCHINA" (Contract number: IC18-CT97-0158). Laboratory analyses of the soil samples were made at the Institute of Soil and Water Conservation in Yangling.

\section{References}

Ansai County, 1985. Soil Resources and its Use. Soil Survey Office, Ansai County.

Bremner, J.M., Mulvaney, C.S., 1982. Nitrogen-total. In: Page, A.L. (Ed.), Methods of Soil Analyses-Part 2Chemical, and Microbiological Properties, 2nd ed. Agronomy, vol. 9. American Society of Agronomy, Madison, WI, USA, pp. 595-624.

Chen, Y.Z., Luk, S.H., 1989. Sediment sources and recent changes in the sediment load of Yellow River, China. In: Rindwanich, S. (Ed.), Land Conservation for Future Generations. Ministry of Agriculture, Bangkok, pp. $313-323$.

FAO, 1990. Guidelines for Soil Profile Description, 3rd ed. (revised). Food and Agricultural Organisation of the United Nations, Rome. 
FAO-UNESCO, 1974. Soil Map of the World (1:5000000). Food and Agricultural Organisation of the United Nations, UNESCO, Paris.

Fu, B., 1989. Soil erosion risk and its control in the loess plateau of China. Soil Use and Management 5, 76-82.

Gong, Z., 1998. The map of soil orders and suborders in Chinese soil taxonomy (1:12000000).

Landon, J.R., 1991. Booker Tropical Soil Manual. Booker Tate; copublisher Wiley, New York.

Lin, Z., Liang, W., 1982. Engineering properties and zoning of loess and loess-like soils in China. Canadian Geotechnical Journal 19, 76-91.

Liu, T., An, Z., Yuan, B., Han, J., 1985. The loess-paleosol sequence in China and climatic history. Episodes 8 , 21-28.

Nelson, D.W, Sommers, L.E., 1982. Total carbon, organic carbon, and organic matter. In: Page, A.L. (Ed.), Methods of Soil Analyses-Part 2-Chemical, and Microbiological Properties, 2nd ed. Agronomy, vol. 9. American Society of Agronomy, Madison, WI, USA, pp. 539-579.

Olsen, S.R., Sommers, L.E., 1982. Phosphorous. In: Page, A.L. (Ed.), Methods of Soil Analyses-Part 2Chemical, and Microbiological Properties, 2nd ed. Agronomy, vol. 9. American Society of Agronomy, Madison, WI, USA, pp. 403-430.

Oyama, M., Takehara, H., 1995. Revised Standard Soil Color Charts. Eijkelkamp Agrisearch Equipment, Soil colour book 08.11. Netherlands.

USDA, 1992. Keys to Soil Taxonomy—5th edition. United States Department of Agriculture. Soil Survey Staff. Pocahontas Press, Blacksburg, Virginia, USA.

van Genuchten, M.T., 1980. A closed-form equation for predicting the hydraulic conductivity of unsaturated soils. Soil Science Society of America Journal 44, 892-898.

WRB, 1998. World reference base for soil resources. World Soil Resources Reports, vol. 84. Food and Agricultural Organisation of the United Nations, Rome. 